\title{
Social education politics in a Europe of inequalities
}

\author{
Javier Bascuñan Cortés* \\ Dpto. Educación Comparada e Historia de la Educación, Universidad de Valencia, Spain \{javier- \\ bascunan@uv.es\} \\ Received on 2 April 2013; revised on 6 April 2013; accepted on 23 April 2013; published on 15 July 2013 \\ DOI: $10.7821 /$ naer.2.2.102-108
}

\begin{abstract}
The aim of this research is to analyse some indicators which allow us to understand the current state of social education politics in Europe, with special reference to Spain. Some European and Spanish social and educational policies which try to confront the challenges of the current financial crisis are also explained. Some deficiencies, failures and contradictions attached to the process of the construction of European citizenship are pointed out. Some key topics which seem to foresee a deeper social and democratic crisis apart from the economic one are tackled. It is explained how the new forms of inequality evidence the failure of some of the important declarations of intent and objectives of the European Union. The subjection of social and democratic aspects to neoliberal economy -i.e. the negation of ideologies - is questioned. To conclude, some key topics are proposed as the central axis through which it could be possible to redefine the content of social education politics in Europe and Spain and to set the bases of a new democratic European citizenship
\end{abstract}

KEYWORDS: POLITICS OF EDUCATION, EDUCATIONAL POLICIES, DEMOCRACY, REGIONAL CHARACTERISTICS

\section{INTRODUCTION}

It can be said that European social and educational politics have covered a lot of ground in their aim for a constant spread of interest towards social issues, education, the deepening of democracy and the extension of European citizenship. This ground gained has been affected by failures and by a top-down design which has resulted in a low social involvement in its results. However, it has accomplished a notable impact on the interest shown by EU institutions and member states, which have included those themes in their political agendas.

The main objective of this article is to analyse the current state of social education politics in Europe, with special reference to on Spain. The analysis will be carried out through the review of some indicators which will allow us to understand the extent, depth and complexity of some necessary changes in social relationships and educational policies. These changes are needed to confront the consequences of a financial crisis that is already showing signs of a wider social and democratic crisis, which may question the bases of the incipient European citizenship.

*To whom correspondence should be addressed:

Universidad de Valencia.

Facultad de Filosofía y Ciencias de la Educación.

Departamento de Educación Comparada e Historia de la Educación.

Avda. Blasco Ibáñez, 30.

46010-Valencia.

Spain.
What is the state of social education politics in Europe and Spain? In order to answer that question, it is necessary to justify what is understood by social education politics, which means framing education within the social structure. It is also necessary to justify how educational policies contribute to the maintenance and transformation of that social structure; in other words, to establish the dialectical relations between education and society. If education is not analysed in relation to social structure, social and cultural change becomes impossible. Thus, our proposal is a critical reflection which analyses different values, assumptions and practices of both educational institutions and society (Armstrong \& Richards, 2011, p. 1).

\subsection{The social structure as a place to interpret educational policies}

In this research, it is considered that educational policies are one of the approaches - the educational one - from which social policies are implemented. At the same time, social policies and their educational component - are the result of the social structure of a given context and historical moment. The transformations in educational policies which negatively affect the quality of the teaching-learning processes present at the different levels of the educational system can be explained as the consequence of two things: either the economic crises which cyclically shake the social structure, or the influence of ideological postulates from which the reform of that same social structure is carried out. In the first case, the economic reasons would make it an obligation to do "more with less" in order to keep up the quality of the teaching-learning processes. In the second case, the ideological reasons would be the ones which would make it an obligation to do "more with less", justifying it as an unavoidable need of carrying out a neoliberal economic reform.

This "more with less" has its consequences, and by no means will improve the quality of social and educational policies. The last FOESSA report published in Spain reveals that the measures which Spain has adopted since 2010 in order to reduce public deficit have been a turning point with regards to access to social rights such as education or assistance to people in situations of dependency. Public budget cuts can affect the quality and efficiency of both systems together with rest of social protection and social security mechanisms which are being implemented at present (Ayala, 2013).

There is not only empirical evidence of how public deficit reduction contributes to a decrease in the quality of current education and social protection systems, but also a prominent theoretical production explaining the transition from welfare states to competitive states (Moos, 2013, p. 21). Welfare states 
and the new competitive states are based on two divergent models regarding social and educational policies. These two models are also based on two different theoretical discourses with opposed concepts. Social justice, political equality or economic equality are being substituted by competitiveness, efficacy, efficiency, budgetary control, framing the availability of the force of labour, of raw materials and capital (Pedersen, 2010, p. 72). Thus, some analysts set out the following question: Citizens or workers? (Noguera, 2004, p. 103). According to Moos: "Economy frames the contemporary state" (2012).

But how is this shift affecting the perception of European and Spanish citizens? Is the withdrawal of social welfare policies affecting the confidence of citizens in their political institutions?

\subsection{The contribution of social education politics to the preservation and the transformation of the social structure}

If the social structure is the place where social and educational policies emerge and, consequently, the framework from which they should be interpreted, social education is then civic education, citizenship education: training with the objective of understanding social structure, learning the skills needed to be part of it and getting an education through the social values which enhance its preservation and transformation. Through all teaching-learning processes developed at the educational system, society contributes to the preservation and the transformation of the social structures in force in order to make them more egalitarian, democratic and equitable, or on the contrary more competitive, antidemocratic and unfair. However, society also has many other institutions, norms and resources which are different from those of the educational system proper, which allow acquiring that same knowledge in different spheres to those of the educational institutions. All learning experiences acquired in educational institutions, but also within the family, at work, in cities or in associations, make it possible to carry out courses of individual or collective action which contribute to the creation of life conditions with higher or lower levels of equality, democracy and equity. Social education politics, in its form of citizenship education, is the political, ideological approach adopted by an educational system and the institutions, norms and resources of a given society in order to educate its citizens for the maintenance and transformation of the social structure in a certain way.

As an example of that point of view, to accomplish the effectiveness of social inclusion policies all pressures of exclusion need to be eliminated from the educational system and the whole society, establishing a dynamic relation between education and society. In education, inclusion is related to a decrease of exclusion of the different learning opportunities, the cultures and communities of the mainstream and an increasing involvement of all of them. Inclusion is a never-ending process through which the land is prepared to enable the accomplishment of an ideal once all excluding pressures within education and society have been eliminated (Booth, 2003, p. 2). In that sense, the principles of the bases of inclusive politics and practice are mainly human rights, equity, social justice and the struggle for a non-discriminatory society (Armstrong \& Barton, 2007, p. 6).

Do European and Spanish citizens consider that equity, attention to diversity and non-discrimination have been affected? Does their perception affect the democratic culture of European citizenship? Is democracy as a system at risk?

\section{MATERIALS AND METHODOLOGY}

In this research, the current state of European social education politics is analysed, with special reference to Spain. The analysis is carried out based on a selection of indicators taken from the Standard Eurobarometer 78, the Special Eurobarometer 393, and the Flash Eurobarometer 373, which are the latest available statistics from the opinion polls carried out by the European Commission. A revision of the European and Spanish literature related to the research objectives has also been carried out and some of the main actions taken by the European Union and Spain regarding social and educational politics have been described.

This descriptive research has adopted a diachronic, hermeneutic, critical approach that seeks the articulation of the historical, cultural, socio-political and contextual dimensions in order to allow a first analysis of the available materials (Horkheimer, 2003). The research question is the current state of social education politics in Europe, with special reference to Spain, and derives from the situations produced by the measures studied in the available documents (Piñuel Raigada, 2002, pp. 89). The structure followed in order to accomplish the objective proposed is description, ordering of data and theorisation (Corbin, 2002, pp. 13-16).

\section{RESULTS AND DISCUSSION}

\subsection{Reforms in education, employment and vocational training}

\subsubsection{The European and Spanish framework: in search of economic growth, competitiveness and employment}

In 2000, the EU adopted the Lisbon Strategy, which sought to make the EU the world's most advanced knowledge economy by 2010 (Lisbon, 2000). The main objectives Europe was supposed to accomplish by 2010 were formulated at the Lisbon summit, but a new Lisbon strategy was launched by the European Council in March 2005 (Commission, 2005) again with growth, competitiveness and the increase of employment opportunities as its essential objectives, based on a report for the European Commission (2004) developed by a group led by Win Kok.

The relations between education, employment and vocational training in Europe has undergone a dramatic, deep transformation during the last decade, regarding both the reform measures adopted and the indicators which are available to analyse and track the results of the reforms.

It should be pointed out that this is due to the content of the directives established by the EU and, especially, to the adaptation of the Lisbon Strategy in each country. Among others, the following initiatives emerged from that process:

- The European Commission White Paper, "A new impetus for European youth" of 2001 (Commission, 2001), compiled in the Council Resolution of June 2002 (Council of the European Union, 2002);

- The Copenhagen Declaration of November 2002 (Copenhagen, 2002);

- The "Education \& Training 2010" interim report, of 26 February 2004, developed jointly by the European Council 
and the European Commission for the European Council (Council and the Commission, 2004);

- The Maastricht Communiqué of 14 December 2014 (Maastricht, 2004);

- The Council's decision taken on 12 July 2005 regarding the employment policy directives for member States, especially directive number 23 (Council of the European Union, 2005);

- The 2005 European Council's subscription of European Youth Pact (Council of the European Union, 2005);

- The Helsinki Communiqué agreed on 5 December 2006 (Helsinki, 2006);

- The Bordeaux Communiqué of 26 November 2008 (Bordeaux, 2008);

- The EU Strategy for Youth of April 2009 (Commission, 2009).

As a consequence of the crisis, a new document developed by the European Commission, -Europe 2020-, insists on formulating some headline targets, some of which are well known. The first of all them refers to the fact that " $75 \%$ of the population aged 20-64 should be employed". The forth one insists on the fact that "the share of early school leavers should be under $10 \%$ and at least $40 \%$ of the younger generation should have a tertiary degree" (European Commission, 2010). The objectives of the aforementioned Lisbon summit related to the improvement of education and training for employment already included some of the educational targets in the new Europe 2020 strategy. This new document tacitly recognises the failure of the revised Lisbon strategy.

This aforementioned EU document's emblematic initiative, "Youth on the move", aims for an improvement in the educational system results and facilitating young people's entry to the labour market through the promotion of students' and trainees' mobility. That objective is expected to be accomplished through the strengthening of results and the international attractiveness of the European higher education institutions, the increase of the overall quality of all levels of education and training in the EU, the combination of excellence and equity and improvement in the working situation of youth. Member states should develop the following actions in their respective levels:

- To ensure efficient investment in education and training systems at all levels (pre-school to tertiary).

- To improve educational outcomes, addressing each segment (pre-school, primary, secondary, vocational and tertiary) within an integrated approach, encompassing key skills and aiming at reducing early school leaving.

- To enhance the openness and relevance of education systems by building national qualification frameworks and better gearing learning outcomes towards labour market needs.

- To improve young people's entry into the labour market through integrated action covering guidance, counselling and apprenticeships, among other aspects.

These global, macro objectives were already included in the measures that came out of the 2000 Lisbon Strategy and would have been difficult to accomplish by many member states, even without the crisis. The forced, hasty effort some countries like
Spain have had to make in order to adapt their previous policies to the new homogeneous reform models of policies has not had enough time to succeed in overcoming the challenges derived from those reforms. In fact, they have also lacked the necessary resources and movement of mechanisms for proper training and retraining of professionals.

Similarly, the new "Education and Training 2020" European strategic framework establishes for objectives (Council, 2009):

- Making lifelong learning and mobility a reality.

- Improving the quality and efficiency of education and training.

- Promoting equity, social cohesion and active citizenship.

- Enhancing creativity and innovation, including entrepreneurship, at all levels of education and training.

It seems clear that the process of European construction is carrying out a convergence of the education and vocational training systems, which has been translated into the establishment of common educational objectives for the beginning of the 20th century. That convergence, in the aforementioned framework of increasing liberalisation, leads to the inclusion of an "obligatory" discourse in the agenda of social policies: "education quality", "promotion of entrepreneurship", "creativity", "competence training" and other key concepts are gradually and successfully changing not only the frameworks, but also the content of the different European educational policies. Quality is understood and assessed as the adaptation of the member states' educational policies to standards defined by quantitative rates and indicators which measure how efficiently the proposed objectives have been met. A positivist empiricism denying any critical approach is ruling right now.

From Lisbon to Copenhagen, from Copenhagen to Maastricht, from Maastricht to Helsinki, from Helsinki to Bordeaux, and up until current times with the new European strategy -Europe 2020 - , the measures to reform the educational, employment and vocational training systems promoted by the EU have aimed to enhance young people's entry to the labour market and have revolved around two core ideas:

- Lifelong learning through the gradual proximity and the equation of teaching-learning processes of formal, nonformal and informal education.

- The approximation of educational and vocational training systems to the needs of the labour market.

However, results are devastating. In January 2013, the EU unemployment rate among the young reached a high level, $23.6 \%$, double that of the adult rate. Around 5.7 million young people are unemployed and more than 7.5 million young people under 25 are not currently working, being educated or trained (Eurostat, 2013). Faced with this data, which shows an alarming growing tendency even before the beginning of the crisis, there is a new Proposal of the European Commission to the European Council of the EU aiming for young people to have a job offer, complementary education or training within four months after they become unemployed or finish formal education. This proposal also explains how to establish a system of Youth Guarantee (European Commission, 2012).

In Spain, the adaptation of education and vocational training to the needs of the labour market has also provoked the promulgation of regulatory measures seeking, to a greater or lesser degree, the adaptation of the whole educational system to 
the main ideas of the aforementioned EU programmes and actions and satisfying the demands of growth, competitiveness and employment. A significant piece of data is the fact that the Spanish educational system has been reformed three times in less than ten years. The first time, the reform was undertaken by the Partido Popular (PP) in 2002 through the Organic Law for the Quality of Education (Ley Orgánica 10/2002, de 23 de diciembre, de Calidad de la Educación), which was never applied. The second reform is still in force and was applied through the Organic Law of Education (Ley Orgánica 2/2006, de 3 de mayo, de Educación) undertaken by the Partido Socialista Obrero Español (PSOE). The third one, which is being developed at the moment, is the Draft Bill of Improvement of Educational Quality (Anteproyecto de Ley Orgánica de Mejora de la Calidad Educativa), drawn up again by the PP after they won the last Spanish general election.

Three educational reforms in such a short period of time are a clear indicator of ideological interest in controlling education. An outstanding debate is that of the existence and the contents of a subject called "Citizen Education". Such debate has taken place even when that subject is theoretical and it contains no references to democratic practices of educational institutions or democratic practices which take place in their premises. The "Depoliticisation" of educational institutions resulting from their disengagement from their social environment and their isolation from life taking place around them has a high cost: the loss of most educational institutions' ability to contribute to the democratic training of its citizens (Morán, 2012, pp. 51-55).

The difficulty of finding that "common us" in the educational system, which is essential to consolidate a civic, democratic culture, is applicable to all European educational systems, though the Spanish case has some specifities. In general, schools are open to the needs of the economic and labour environment, but not so much to the social and cultural one. In Spain, moreover, there is the debate around the "Citizen Education" subject.

Regarding the specific reform of vocational training and its adaptation to the demands of the labour market, Spain has made a considerable effort during recent years. That effort can be observed in different regulations: the Organic Law on Qualifications and Vocational Training (Ley Orgánica 5/2002, de 19 de junio, de las Cualificaciones y de la Formación Profesional), the Law of Employment (Ley 56/2003, de 16 de diciembre, de Empleo), the Royal Decree to regulate vocational training within the educational system (Real Decreto 1538/2006, de 15 de diciembre, por el que se establece la ordenación general de la formación profesional del sistema educativo), the Royal Decree to regulate the vocational training subsystem for employment (Real Decreto 395/2007, de 23 de marzo, por el que se regula el subsistema de formación profesional para el empleo), the Royal Decree to recognise professional skills acquired through work experience (Real Decreto 1224/2009, de 17 de julio, de reconocimiento de las competencias profesionales adquiridas por experiencia laboral), or the Royal Decree to regulate vocational training within the educational system (Real Decreto $1147 / 2011$, de 29 de julio, por el que se establece la ordenación general de la formación profesional del sistema educativo). Two legislative reforms are especially significant in the shift which has taken place in Spanish social and educational policies: the Government Decree of urgent measures to reform the labour market (Real Decreto-ley 10/2010, de 16 de junio, de medidas urgentes para la reforma del mercado de trabajo) and the Government Decree of urgent measures to rationalise public expenditures in the educational sphere (Real Decreto-ley 14/2012, de 20 de abril, de medidas urgentes de racionalización del gasto público en el ámbito educativo).

Despite all these measures, the youth unemployment rate has increased as in the whole of Europe, but up to much higher levels. In January 2013, it reached 55.5\%. Only Greece reached a higher rate $(59.4 \%$ in November 2012$)$, in both cases more than double the adult rate (Eurostat, 2013). As in the in the EU, expectations are that the situation will get worse. Would it make sense to speak about "systems of expulsion" from the labour market? (Gil Rodríguez, 2011).

\subsection{The challenges of European and Spanish citizenship in cash societies}

\subsubsection{How is the crisis in European and Spanish citizenship having influence with respect to the quality of systems for social protection and current education?}

Citizens are aware that the containment of the public deficit contributes to the decrease in quality of social protection and educational systems in force not only in Spain but also in Europe. In 2012, the majority of European citizens (54\%, +5 percent points since 2009) consider that due to the financial crisis, policies of promotion of equality and diversity are judged as less important and are financed worse. In the case of Spain, said percentage rises to $66 \%$ (TNS Opinion \& Social, 2012c).

Citizens' fears are the result of the ascertainment of the inevitable: loss of quality in public service, an imperatively neoliberal financial argument which wishes to show itself as aseptic, non-ideological. However, it is ideological and political: it is convenient for them to emphasise that the solution to the crisis depends on neoliberal economic solutions, avoiding the fact that the solutions are the problem that causes it.

That objective has been effectively achieved: according to the results of the Eurobarometer from Autumn 2012 for UE27, the leading places among the concerns of all Europeans nationally are occupied by economic subjects (unemployment 48\%, economic situation $37 \%$, prices/inflation $24 \%$ ). In the same survey, and also for UE27, the educational system only concerns, nationally, $7 \%$ of Europeans. Personally, the principal concerns of UE27 citizens are the same, although in a different order (prices/inflation 44\%, unemployment $21 \%$, economic situation 19\%). Also in this case, that is to say, on a personal level, the educational system only concerns $9 \%$ of Europeans. Concern over economic subjects continues to be higher than that which exists with respect to social questions (TNS Opinion \& Social, 2012a).

With regards to Spain, nationally, unemployment becomes the leading reason for Spanish people's concern, with $78 \%$, thirty points more than the European average, followed by the economic situation, with $55 \%$, eighteen points more than the European average, while the rise in prices and inflation only concern $9 \%$ of Spanish people, fifteen points less the European average, which concerns them more than public debt and the health system and social security, both with $10 \%$. The educational system only concerns $4 \%$ of Spanish people nationally, three points less than the European average. On a personal level, the educational system concerns $10 \%$ of Spanish people, while unemployment is their main concern (43\%), followed by the economic situation (32\%), and the rise in prices 
and inflation (29\%). Obviously, unemployment and the economic situation of the country almost monopolise Spanish people's preoccupations (TNS Opinion \& Social, 2012b). Nevertheless, to cite just one example, the school drop-out rate in our country in 2011, one of the highest in Europe, was 26.5\% (Ayala, 2013, p. 21).

\subsubsection{Does the abandonment of welfare policies affect the confidence of citizenship in their political institutions?}

Not without cause, between the Eurobarometer of Autumn 2004 and that of Autumn 2012, the confidence of Europeans in EU institutions went down from $50 \%$ to $33 \%$, a decrease of $17 \%$, much more than that demonstrated towards the national parliaments and governments, institutions that in the same period have "only" seen confidence placed in them decrease from $10 \%$ to $7 \%$ respectively (TNS Opinion \& Social, 2012a).

With reference to Spain, and in the latest Eurobarometer, confidence in the national government is $11 \%$, noticeably lower than the EU average (27\%), the same as confidence in the national parliament, which in Spain is $9 \%$, while it is $28 \%$ in the European average and in European institutions, while among Spanish people it is $20 \%$ when compared to $33 \%$ in Europe in the same category. Only confidence in regional and local public authorities exceed the low percentages of confidence indicated, although still with lower percentages in Spain than in Europe ( $43 \%$ in the EU compared to $21 \%$ in Spain) (TNS Opinion \& Social, 2012b). This is not to mention distrust towards politics in general.

Nevertheless, and according to the data from the same 2012 Eurobarometer, Spanish citizens are among those who feel the most European in all the member states, even though Spain is under the European average regarding the existence of union links with the other EU states. Like all EU citizens, the European right which the Spanish would like to know more about is that of "working in another EU country", although with a noticeable difference, while in the EU said percentage is $37 \%$, in Spain this rises to $43 \%$, increasing to $61 \%$ among the unemployed and to $64 \%$ among students. It is more evident that in contexts of youth unemployment rates, like those identified in the characteristic initiative "Youth on the move", involves a "movement that is forced" by the search for work (López, Gil, \& Bascuñán, 2013).

It continues to surprise that in self-positioning among the various social classes, $70 \%$ of Spanish people consider themselves to be "society's working class", 28 points more than the EU average, while $27 \%$ consider themselves to be "middle class", 22 points less than the average for European citizens (Aranda, 2012). The answer to the question posed earlier, Citizens or workers?, is clear for Spanish people.

\subsubsection{Do European and Spanish citizens consider that equality, attention to diversity, and non- discrimination have been affected?}

The financial cuts in social and education policies involve greater discrimination. According to the data from the special 2012 Eurobarometer, limited access to goods and services is considered as discrimination against disabled people and older people by more than two thirds of Europeans (68\%) (TNS Opinion \& Social, 2012c). 45\% of Europeans believe that discrimination against people over 55 is common, while discrimination against those under 30 is considered much less common -only $18 \%$ believe that discrimination is very extended (TNS Opinion \& Social, 2012c, p. 119).

The fact that this age-based discrimination is perceived principally as a question related to employment is verified in the measure in which many Europeans believe that equal opportunities in employment could be improved: it is considered that many personal characteristics can put those looking for work in an unfavourable position during the contracting process. Being over 55 is considered the principal factor that can lead to a situation of inequality. Actually, more than half of Europeans $(54 \%)$ believe that the age of the person looking for work is an obstacle if the person is older than 55; disability (40\%), skin colour and ethnic origin (39\%) are also considered as obstacles. In the case of Spain, the percentage of those surveyed who agree in considering that age is an obstacle in access to employment for those over 55 rises to $66 \%$ (TNS Opinion \& Social, 2012c, p. $88)$.

Greater discrimination involves greater danger of equal opportunities in access to employment, particularly among those over 55, disabled people and ethnic minorities. In 2012, more than two thirds of Europeans (67\%) believe that the crisis generates more economic discrimination against workers of advanced age (over 55). More than half of Europeans also believe that due to the financial crisis, discrimination in the labour market for reasons of disability (53\%) and ethnicity $(52 \%)$ has increased (TNS Opinion \& Social, 2012c).

All this indicates that the high rates of youth unemployment are not considered discriminatory in access to employment because the problem is that there is simply no employment, not that access to the same is closed to young people for being young, as does indeed happen with the other groups identified.

\subsubsection{Does that perception affect the democratic culture of European citizens? Is this democracy as a system at risk?}

The data also questions the myth of the Relational State, based on the importance of voluntary workers and reciprocity in the provision of welfare through bodies in the third sector as an alternative to the Welfare State (Bascuñán, 2012, pp. 179-185). According to the data in the 2013 flash Eurobarometer, while in the EU the majority of Europeans consider that nongovernmental organisations and associations share their ideals and values (59\%), Spain is one of the three exceptions (together with the Czech Republic and Estonia) in which the contrary opinion is the majority: said bodies do not share their ideals and values. While in the EU "only" $41 \%$ of those surveyed consider that NGOs and associations are not necessary, in five member states (Romania, Greece, Bulgaria, Portugal and Cyprus) the contrary opinion is the majority: they are not necessary (TNS Opinion \& Social, 2013, pp. 4-9). The countries most affected by the financial crisis are the most reticent in accepting the role of said bodies in the provision of welfare services which are alternative or complementary to those of the State.

The effectiveness of the vote in the regional / local or national setting is better perceived than the vote in European elections or than participation in associative bodies. While around $70 \%$ of those surveyed in the EU believe that the vote in the local/ regional or national setting is an efficient way of influencing political decisions, "only" around 50\% think that the vote in EU elections or joining an NGO is effective in the same way. Spain is 12 points below the European percentage regarding the effectiveness of the local / regional vote, 11 points below regarding the national vote, 4 points below regarding the 
European vote and 5 points below regarding effectiveness in joining an NGO (TNS Opinion \& Social, 2013).

The participation data in associative bodies are not particularly high. A fifth of those Europeans surveyed (20\%) say that they are members of a financial, social, environmental, cultural or sporting organisation. Around one person in every six is also a member of other kinds of specific organisations (17\%), or a member of a union (16\%). A tenth (11\%) of those surveyed are members of a professional association for groups such as doctors or teachers. Relatively few people are members of other kind of associations such as Chambers of Commerce $(5 \%)$ or business organisations (4\%) (TNS Opinion \& Social, 2013, pp. $31-33)$.

\section{CONCLUSIONS. DISORIENTATION, RISKS, UNCERTAINTY... THE CHALLENGES OF SOCIAL EDUCATION POLITICS IN NEW CASH SOCIETIES}

Social education politics in Europe and Spain must pay special attention to the ways in which civic involvement is specified in younger generations as a consequence of the transformations which socially and educationally is producing the neoliberal economic response to the crisis that is all around Europe (Benedicto et al., 2011; Benedicto \& López, 2008).

Accessing and remaining in the educational system is becoming more and more difficult for many social sectors as a consequence of the budget cuts. The relative openness of the educational and training systems for those who have conditions to access to them is not leading to job opportunities in the labour market. However, in the opinion of European and Spanish citizens, low concern about education has no relation at all with the high concern about employment. It is as though education opportunities were unrelated to job opportunities in a framework in which financial concerns monopolise everything.

Apart from employment, however, the educational system also needs to be opened up to society and politics. This corresponds to the need to open up society towards an education that is not strictly financial, but political and social. If, as has been noted, "economy frames the contemporary state", society and politics must recover ground lost to the economy. It is necessary to reduce all the pressures of exclusion, not only in the educational system, but also throughout society and its remaining social policies.

\section{REFERENCES}

Anteproyecto de Ley Orgánica de Mejora de la Calidad Educativa (2012). Retrieved from http://www.stecyl.es/borralex/LOMCE/Anteproyecto_LOMCE_septi embre2012.pdf

Aranda Palmero, E. (2012). Eurobarómetro estándar 78. Opinión pública en la Unión Europea. Otoño 2012. Informe nacional. España. Representación en España de la Comisión Europea. Retrieved from http://ec.europa.eu/public_opinion/archives/eb/eb78/eb78_es_es_nat. pdf

Armstrong, F. \& Barton, L. (2007). Policy, experience and change and the challenge of inclusive education the case of England. In L. Barton \& F. Armstrong (Eds.), Policy, Experience and Change: Crosscultural Reflections on Inclusive Education. London: Springer. doi: 10.1007/978-1-4020-5119-7_2

Armstrong, F. \& Richards, G. (2011). Introduction. In G. Richards \& F. Armstrong (Eds.), Teaching and learning in diverse and inclusive classrooms. London and New York: Routledge.

Ayala Cañón, L. (2013). Analizamos los indicadores sociales. In Comité Técnico de la Fundación FOESSA (Coord.), Análisis y perspectivas
2012. Exclusión y desarrollo social. Madrid: Fundación FOESSA Cáritas Española.

Bascuñán, J. (2012). La democracia como trabajo. Jóvenes entre la comunidad local y la sociedad global. In G. Gil, A. López, \& L. B. Muñoz (Coord.), Jóvenes y ciudad. Espacios de relación y protesta. Valencia: Asociación Regional y Europea de Análisis.

Benedicto, J. et al. (2011). La construcción del sujeto político en la juventud. El caso de los jóvenes andaluces en riesgo. Sevilla: Centro de Estudios Andaluces.

Benedicto, J. \& López, A. (2008). Jóvenes y participación política. Investigaciones europeas. In J. Benedicto \& A. López (Coord.), Revista de Estudios de Juventud (Junio), 81.

Booth, T. (2003). Inclusion and exclusion in the city: concepts and contexts. In P. Potts, (Ed.), Inclusion in the City: Selection, Schooling and Community. London: RoutledgeFalmer.

Bordeaux Communiqué (2008). The Bordeaux Communiqué on enhanced European cooperation in vocational education and training. Communiqué of the European Ministers for vocational education and training, the European social partners and the European Commission, meeting in Bordeaux on 26 November 2008 to review the priorities and strategies of the Copenhagen process. Retrieved from http://ec.europa.eu/education/lifelong-learningpolicy/doc/bordeaux_en.pdf

Commission of the European Communities (2001). European Commission White Paper. A new impetus for European youth. Brussels, 21.11.2001 $\operatorname{COM}(2001) \quad 681$ final. Retrieved from http://ec.europa.eu/youth/documents/publications/whitepaper_en.pdf

Commission of the European Communities (2005). Communication to the spring European Council. Working together for growth and jobs. A new start for the Lisbon Strategy. Brussels, 2.2.2005 COM(2005) 24 final. Retrieved from http://eurlex.europa.eu/LexUriServ/LexUriServ.do?uri=COM:2005:0024:FIN: EN:PDF

Commission of the European Communities (2009). Communication from the Commission to the Council, the European Parliament, the European Economic and Social Committee and the Committee of the Regions. An EU Strategy for Youth - Investing and Empowering. A renewed open method of coordination to address youth challenges and opportunities. Brussels, 27.4.2009 COM(2009) 200 final. Retrieved from http://eurlex.europa.eu/LexUriServ/LexUriServ.do?uri=COM:2009:0200:FIN: EN:PDF

Council and Commission (2004). "Education \& training 2010" The Success of the Lisbon strategy hinges on urgent reforms. Joint interim report of the Council and the Commission on the implementation of the detailed work programme on the follow-up of the objectives of education and training systems in Europe. 26.2.2004 Retrieved from http://ec.europa.eu/education/policies/2010/doc/jir_council_final.pdf

Council conclusions (2009). Council conclusions of 12 May 2009 on a strategic framework for European cooperation in education and training ('ET 2020') (2009/C 119/02) Official Journal of the European Union. 28.5.2009 Retrieved from http://eurlex.europa.eu/LexUriServ/LexUriServ.do?uri=OJ:C:2009:1 19:0002: 0010:EN:PDF

Council Decision (2005). Council Decision of 12 July 2005 on Guidelines for the employment policies of the Member States (2005/600/EC). Official Journal of the European Union 6.8.2005 Retrieved from http://eurlex.europa.eu/LexUriServ/LexUriServ.do?uri=OJ:L:2005:205:0021:0 027:EN:PDF

Council of the European Union (2002). Resolution of the Council and of the Representatives of the Governments of the Member States, meeting within the Council of the 27 June 2002 regarding the framework of European cooperation in the youth field (2002/C 168/02) Official Journal of the European Communities 13.7.2002 Retrieved from http://eur-

lex.europa.eu/LexUriServ/LexUriServ.do?uri=OJ:C:2002:168:0002: 0005:EN:PDF

Council of the European Union (2005). Presidency Conclusions - Brussels, 22 and 23 March 2005. Retrieved from http://www.consilium.europa.eu/uedocs/cms_data/docs/pressdata/en/ ec/84335.pdf

Copenhagen Declaration (2002). Declaration of the European Ministers of Vocational Education and Training, and the European Commission, convened in Copenhagen on 29 and 30 November 2002, on en- 
hanced European cooperation in vocational education and training. Retrieved from http://ec.europa.eu/education/pdf/doc125_en.pdf

Corbin, J. \& Strauss, A. (2002). Bases de la investigación cualitativa. Medellín: Editorial Universidad de Antioquía.

European Commission (2010). Communication from the Commission Europe 2020 A strategy for smart, sustainable and inclusive growth. Brussels, 3.3.2010 COM (2010) 2020 final. Retrieved from http://eur-

lex.europa.eu/LexUriServ/LexUriServ.do?uri=COM:2010:2020:FIN: EN:PDF

European Commission (2012);.Proposal for a Council Recommendation on establishing a Yoth Guarantee. Brussels, 5.12.2012 COM (2012) 729 final. Retrieved from http://eurlex.europa.eu/LexUriServ/LexUriServ.do?uri=COM:2012:0729:FIN: $\mathrm{EN}: \mathrm{PDF}$

Eurostat (2013). January. Unemployment statistics. Retrieved from http://epp.eurostat.ec.europa.eu/statistics_explained/index.php/Unem ployment statistics

Gil Rodríguez, G. (2011). Sistemas de expulsión: jóvenes, inmigrantes, mujeres en la formación y en el mercado laboral. In A. López, G. Gil, \& Á. Iglesia (Coord.), Jóvenes y cambio social global. Respuestas políticas en ciudades europeas. Valencia: Asociación Regional y Europea de Análisis.

Helsinki Communiqué (2006). The Helsinki Communiqué on Enhanced European Cooperation in Vocational Education and Training. Communique of the European Ministers of Vocational Education and Training, the European Social partners and the European Commission, convened in Helsinki on 5 December 20063 to review the priorities and strategies of the Copenhagen Process. Retrieved from http://www.cedefop.europa.eu/EN/Files/helsinkicom_en.pdf

High Level Group (2004). Facing the challenge. The Lisbon strategy for growth and employment. Report from the High Level Group chaired for Win Kok. Luxembourg: Office for Official Publications of the European Communities.

Horkheimer, M. (2003). Teoría Crítica. Buenos Aires: Amorrortu editores.

Ley 56/2003, de 16 de diciembre, de Empleo (Boletín Oficial del Estado $\mathrm{N}^{\mathrm{o}} 301$ del 17 de diciembre de 2003).

Ley Orgánica 5/2002, de 19 de junio, de las Cualificaciones y de la Formación Profesional (Boletín Oficial del Estado $\mathrm{N}^{\mathrm{o}} 147$ del 20 de junio de 2002)

Ley Orgánica 10/2002, de 23 de diciembre, de Calidad de la Educación (Boletín Oficial del Estado No 307 del 24 de diciembre de 2002).

Ley Orgánica 2/2006, de 3 de mayo, de Educación (Boletín Oficial del Estado $\mathrm{N}^{\mathrm{o}} 106$ del 4 de mayo de 2006).

Lisbon European Council (2000); 23 and 24 march. Presidency conclusions. Retrieved

from http://www.europarl.europa.eu/summits/lis1 en.htm

López, A., Gil, G., \& Bascuñán, J. (2013). Von der Mobilität als Lebensprojekt bis die "Mobilität unter Druck" in Rahmen der EU: der Fall Spanien. In Kongress, Building Tomorrow's Europe (7 - 8 Mai, 2013) in Bonn.

Maastricht Communiqué (2004). Maastricht Communiqué on the Future Priorities of Enhanced European Cooperation in Vocational Education and Training (VET) (Review of the Copenhagen Declaration of 30 November 2002). Retrieved from http://ec.europa.eu/education/news/ip/docs/maastricht_com_en.pdf

Moos, L. (2013). School leadership in a contradictory World, Revista de Investigación Educativa, 31(1), 15 - 29.

Moos, L. (2012). Educational leadership in a competitive state: a contradiction in terms? In International Journal of Educational Management, 26(5), 461 - 469. doi: 10.1108/09513541211240255

Morán, M. L. (2012). Los jóvenes españoles en los espacios de aprendizaje de la ciudadanía, In G. Gil, A. López, \& L. B. Muñoz (Coord.), Jóvenes y ciudad. Espacios de relación y protesta. Valencia: Asociación Regional y Europea de Análisis.

Noguera, J. A. (2004). Citizens or workers? Basic income vs. Welfare to Work Policies, Routges Journal of Law \& Urban Policy, 2(1), 103 124.

Pedersen, O. K. (2010). Konkurrencestaten [The competitive state]. Copenhagen: Hans Reitzels Forlag.

Piñuel Raigada, J. L. (2002). Epistemología, metodología y técnicas del análisis de contenido. In M. A. Arias (Coord.), Estudios de sociolingüistica: Linguas, sociedades e culturas (Vol. 3, (1)).

Real Decreto 1538/2006, de 15 de diciembre, por el que se establece la ordenación general de la formación profesional del sistema educativo (Boletín Oficial del Estado $\mathrm{N}^{\mathrm{o}} 3$ del 3 de enero de 2007).
Real Decreto 395/2007, de 23 de marzo, por el que se regula el subsistema de formación profesional para el empleo (Boletín Oficial del Estado $\mathrm{N}^{\circ} 87$ del 11 de abril de 2007)

Real Decreto 1224/2009, de 17 de julio, de reconocimiento de las competencias profesionales adquiridas por experiencia laboral (Boletín Oficial del Estado $\mathrm{N}^{\circ} 205$ del 25 de agosto de 2009).

Real Decreto-ley 10/2010, de 16 de junio, de medidas urgentes para la reforma del mercado de trabajo (Boletín Oficial del Estado $\mathrm{N}^{\mathrm{o}} 147$ del 17 de junio de 2010).

Real Decreto 1147/2011, de 29 de julio, por el que se establece la ordenación general de la formación profesional del sistema educativo (Boletín Oficial del Estado $\mathrm{N}^{\mathrm{o}} 182$ del 30 de julio de 2011).

Real Decreto-ley 14/2012, de 20 de abril, de medidas urgentes de racionalización del gasto público en el ámbito educativo (Boletín Oficial del Estado $\mathrm{N}^{\mathrm{o}} 96$ del 21 de abril de 2012).

TNS Opinion \& Social (2012a). Standard Eurobarometer 78. Autumn 2012. Public opinion in the European Union. First results. European Commission's. Directorate-General for Communication. Retrieved from

http://ec.europa.eu/public_opinion/archives/eb/eb78/eb78_first_en.pd

TN $\bar{S}$ Opinion \& Social (2012b). Standard Eurobarometer 78. Tables of results. First results. Public opinion in the European Union. Fieldwork: november 2012. European Commission's. Directorate-General for Communication. Retrieved from http://ec.europa.eu/public_opinion/archives/eb/eb78/eb78_anx_en.pd

TNS̄ Opinion \& Social (2012c). Special Eurobarometer 393. Discrimination in the European Union in 2012. Report. november 2012. European Commission, Directorate-General Justice and co-ordinated by Directorate-General for Communication. Retrieved from http://ec.europa.eu/public_opinion/archives/ebs/ebs_393_en.pdf

TNS Opinion \& Social (2013). Flash Eurobarometer 373. Europeans Engagement in participatory democracy. Report. February 2013. European Commission's. Directorate-General for Communication. Retrieved from http://www.eesc.europa.eu/resources/docs/fl373--report-final-en.pdf

\section{ACKNOWLEDGMENT}

This article is framed within the project "Proyecto Leonardo: TTV Tools of the Trade for Teaching in VET (vocacional educational training)", 1.10.2011-30.09.2013. It has been funded by the European Commission, Direction of Education and Culture and coordinated by Handwerkskammer Freiburg (Chamber of Crafts), Germany, in partnership with IRIS e. V., Tübingen (Germany), AREA Valencia (Spain), GENESIS Bologna (Italy) and SOLARIS Pitesti (Romania). 